University of Wollongong

Research Online

Faculty of Law, Humanities and the Arts Papers (Archive)

Faculty of Arts, Social Sciences \& Humanities

$1-1-2016$

Deep-sea genetic resources: new frontiers for science and stewardship in areas beyond national jurisdiction

Harriet Harden-Davies

University of Wollongong, hrhd829@uowmail.edu.au

Follow this and additional works at: https://ro.uow.edu.au/lhapapers

Part of the Arts and Humanities Commons, and the Law Commons

Research Online is the open access institutional repository for the University of Wollongong. For further information contact the UOW Library: research-pubs@uow.edu.au 


\title{
Deep-sea genetic resources: new frontiers for science and stewardship in areas beyond national jurisdiction
}

\author{
Abstract \\ The deep-sea is a large source of marine genetic resources (MGR), which have many potential uses and \\ are a growing area of research. Much of the deep-sea lies in areas beyond national jurisdiction (ABNJ), \\ including $65 \%$ of the global ocean. MGR in ABNJ occupy a significant gap in the international legal \\ framework. Access and benefit sharing of MGR is a key issue in the development of a new international \\ legally-binding instrument under the United Nations Convention on the Law of the Sea (UNCLOS) for the \\ conservation and sustainable use of marine biological diversity in ABNJ. This paper examines how this is \\ relevant to deep-sea scientific research and identifies emerging challenges and opportunities. There is no \\ internationally agreed definition of MGR, however, deep-sea genetic resources could incorporate any \\ biological material including genes, proteins and natural products. Deep-sea scientific research is the key \\ actor accessing MGR in ABNJ and sharing benefits such as data, samples and knowledge. UNCLOS \\ provides the international legal framework for marine scientific research, international science \\ cooperation, capacity building and marine technology transfer. Enhanced implementation could support \\ access and benefit sharing of MGR in ABNJ. Deep-sea scientific researchers could play an important role \\ in informing practical new governance solutions for access and benefit sharing of MGR that promote \\ scientific research in ABNJ and support deep-sea stewardship. Advancing knowledge of deep-sea \\ biodiversity in $A B N J$, enhancing open-access to data and samples, standardisation and international \\ marine science cooperation are significant potential opportunity areas.

\section{Disciplines} \\ Arts and Humanities | Law

\section{Publication Details} \\ H. Harden-Davies, 'Deep-sea genetic resources: new frontiers for science and stewardship in areas \\ beyond national jurisdiction' (2017) 137 Deep-Sea Research Part 2: Topical Studies in Oceanography \\ 504-513.
}




\title{
DEEP-SEA GENETIC RESOURCES: NEW FRONTIERS FOR SCIENCE AND STEWARDSHIP IN AREAS BEYOND NATIONAL JURISDICTION
}

\author{
Harriet Harden-Davies*
}

Australian National Centre for Ocean Resources and Security, University of Wollongong, Innovation Campus, Wollongong, NSW, 2522, Australia

*E-mail: hrhd829@uowmail.edu.au

\begin{abstract}
The deep-sea is a large source of marine genetic resources (MGR), which have many potential uses and are a growing area of research. Much of the deep-sea lies in areas beyond national jurisdiction (ABNJ), including $65 \%$ of the global ocean. MGR in ABNJ occupy a significant gap in the international legal framework. Access and benefit sharing of MGR is a key issue in the development of a new international legally-binding instrument under the United Nations Convention on the Law of the Sea (UNCLOS) for the conservation and sustainable use of marine biological diversity in ABNJ. This paper examines how this is relevant to deep-sea scientific research and identifies emerging challenges and opportunities. There is no internationally agreed definition of MGR, however, deep-sea genetic resources could incorporate any biological material including genes, proteins and natural products. Deep-sea scientific research is the key actor accessing MGR in ABNJ and sharing benefits such as data, samples and knowledge. UNCLOS provides the international legal framework for marine scientific research, international science cooperation, capacity building and marine technology transfer. Enhanced implementation could support access and benefit sharing of MGR in ABNJ. Deep-sea scientific researchers could play an important role in informing practical new governance solutions for access and benefit sharing of MGR that promote scientific research in ABNJ and support deep-sea stewardship. Advancing knowledge of
\end{abstract}


deep-sea biodiversity in ABNJ, enhancing open-access to data and samples, standardisation and international marine science cooperation are significant potential opportunity areas. ${ }^{1}$

KEYWORDS: Law of the sea; international law; marine resources; ocean policy; marine genetic resources; areas beyond national jurisdiction; high seas; access and benefit sharing.

\section{INTRODUCTION}

The rich biological diversity of the deep-sea is a source of vast genetic and biochemical diversity with a range of potential applications, from advancing scientific knowledge to developing new commercial products (Martins et al., 2014, Skropeta and Wei, 2014). These so-called "marine genetic resources",2 (MGR) are one of the ecosystem services provided by the deep-sea (Armstrong et al., 2012, Rogers et al., 2014). Genetic resources play a growing role in various economic sectors (EU, 2014, Rogers et al., 2015), including: pharmaceuticals, agriculture, biotechnology, bioremediation, cosmetics, food, nutraceuticals, industrial processes and scientific research (Martins et al., 2014, Oldham et al., 2014, Leary et al., 2009). However, there are significant gaps in the international legal framework for MGR in marine areas beyond national jurisdiction $(\mathrm{ABNJ})$, which encompass $65 \%$ of the ocean surface and $95 \%$ of the ocean volume (FAO, 2014). The governance questions relating to MGR in ABNJ raise many issues pertinent to deep-sea scientific research and are drawing attention at the international scale.

The development of a new international legally-binding instrument (ILBI) under the 1982 United Nations Convention on the Law of the Sea (UNCLOS) for the conservation and sustainable use of marine biological diversity in ABNJ (UN, 2015) ${ }^{3}$ is underway. This comes

\footnotetext{
${ }^{1}$ Abbreviations: Areas beyond national jurisdiction (ABNJ); Marine genetic resources (MGR); United Nations Convention on the Law of the Sea (UNCLOS).

${ }^{2}$ See section 2.1 for definition.

${ }^{3}$ The United Nations General Assembly (UNGA) adopted Resolution 69/292, "Development of an international legally-binding instrument under the United Nations Convention on the Law of the Sea on the conservation and sustainable use of marine biological diversity of areas beyond national jurisdiction", on 19 June 2015. A Preparatory Committee will meet four times between 2016 and 2017 and report to the United Nations General Assembly on its progress by the end of 2017. States will decide by September 2018 whether to convene an intergovernmental conference to begin negotiations on a new agreement under UNCLOS.
} 
after almost a decade of deliberations by an informal working group. ${ }^{4}$ A new ILBI could address gaps and fragmentation in the existing international legal framework (Druel and Gjerde, 2014, Warner, 2014). This is a critical step for deep-sea stewardship ${ }^{5}$ that could facilitate international cooperation for sustainable management (Rochette et al., 2015, Warner, 2014) and promote new action needed to address the numerous and growing threats to deep-sea biodiversity (Benn et al., 2010, Halpern et al., 2008, Ramirez-Llodra et al., 2011, Van Dover, 2014, Van Dover et al., 2014) in ABNJ. MGR are a complex and highly contentious issue for the negotiations for a new ILBI, which will also consider: area-based management tools, including marine protected areas; environmental impact assessments; and capacity building and the transfer of marine technology. The key governance challenges for MGR in ABNJ can be summarised in three points:

- $\quad$ Lack of definition of MGR \& unclear legal status in ABNJ. There is no internationally agreed definition of MGR - the term is not mentioned or defined by UNCLOS (Section 2.1, Table 1). The applicability of the principle of freedom of the high seas ${ }^{6}$ and/or common heritage of mankind ${ }^{7}$ to MGR in ABNJ is a polarising issue between developed and developing States (Broggiato et al., 2014, Houghton, 2014, Wright et al., 2016).

- $\quad$ Lack of definition of marine scientific research. The legal status of activities involving access to MGR in ABNJ is unclear. Marine scientific research, the primary activity accessing MGR in ABNJ (EU, 2014, Oldham et al., 2014), is not defined by UNCLOS. There are longstanding issues relating to the distinction between commercial (i.e. industrial or applied) and non-commercial (i.e. pure or basic) marine scientific research (UN, 2010). As new technologies drive

\footnotetext{
${ }^{4}$ The Ad Hoc Open-ended Informal Working Group to study issues relating to the conservation and sustainable use of marine biological diversity beyond areas of national jurisdiction met nine times between 2006 and 2015. ${ }^{5}$ Mengerink et al., (2014) refer to deep ocean stewardship in the context of "moving from a frontier mentality of exploitation and single-sector management to a precautionary system that balances use of living marine resources, energy, and minerals from the deep ocean with maintenance of a productive and healthy marine environment, while improving knowledge and collaboration".

${ }^{6}$ Freedom of the high seas applies to marine scientific research, navigation, overflight, laying submarine cables and pipelines, constructing installations and fishing (UNCLOS article 87).

${ }^{7}$ The sea-bed, ocean floor and subsoil in ABNJ (the Area), including its mineral resources, are the common heritage of mankind (1970 Declaration of Principles Governing the Sea-Bed and the Ocean Floor and the Subsoil Thereof, Beyond the Limits of National Jurisdiction, UNCLOS article 136). Benefits from mineral resources in the Area are to be equitably shared with all mankind by the International Seabed Authority.
} 
transformative change in where, how and by whom marine scientific research can be conducted, the boundary between pure and applied scientific research becomes increasingly blurred (Harden-Davies, 2015). This raises complex governance questions for research activities, such as those involved in MGR in ABNJ, that cross both non-commercial and commercial research.

- $\quad$ Lack of applicable access and benefit-sharing instrument: MGR in ABNJ could be a source of new knowledge and biotechnology, however, few countries have the financial, technological and other means necessary to access and use MGR in ABNJ (Arnaud-Haond et al., 2011, Juniper, 2013). Existing access and benefit sharing regimes, most notably the 2010 Nagoya Protocol on Access to Genetic Resources and the Fair and Equitable Sharing of Benefits Arising from the Utilisation to the Convention on Biological Diversity (Nagoya Protocol), are not applicable in ABNJ. Access to MGR in ABNJ is currently open and there is no formal benefit sharing mechanism. ${ }^{8}$

The development of a new access and benefit sharing regime is a favoured option to achieve compromise and develop a governance solution for MGR in ABNJ, as part of a new ILBI. ${ }^{9}$ Deep-sea scientific research is a critically important actor in the development of a new access and benefit regime for MGR in ABNJ. For example, deep-sea scientific research is currently the primary activity accessing MGR in ABNJ (McMeel et al., 2014, Oldham et al., 2014) and accurate taxonomic and geographic data is important for natural products research (Leal et al., 2016). Furthermore, much of the deep-sea lies in ABNJ. ABNJ includes many priority areas for the investigation of deep-sea chemosynthetic ecosystems - including areas of the East Pacific Rise, the mid-Atlantic Ridge, South-west Indian Ridge and South-east Indian Ridge (German et al., 2011) - and the deep-sea observatory at the Porcupine Abyssal Plain in the North Atlantic. It is therefore important that deep-sea scientists are aware of the potential

\footnotetext{
${ }^{8}$ For more information on the legal and governance challenges of MGR in ABNJ, including issues relating to access and benefit sharing and patents, see for example: Broggiato et al., 2014, Glowka, 2010, Greiber, 2013, Leary et al., 2009.

${ }^{9}$ Traditionally, the G77+China developing States have favoured the application of the principle of common heritage of mankind to MGR in ABNJ and the development of an access and benefit sharing regime, whilst technologically advanced developed States (including USA and Japan) have been opposed to this (see ArnaudHaond, et al., 2011). However, discussions at the first Preparatory Committee meeting (PrepCom 1) for the development of a new ILBI (28 March - 8 April 2016, New York) showed signs of convergence on the need to develop an access and benefit sharing regime.
} 
implications for scientific research from a new ILBI, and how scientific research could be a key non-State actor in informing the development of the new instrument.

The aim of this paper is to examine why the development of a new ILBI is relevant to deepsea scientific research and how deep-sea scientific research can inform the development of an access and benefit sharing regime of MGR in ABNJ. This paper draws on an analysis of the international legal framework for marine scientific research and genetic resources and an examination of the role of deep-sea science in access and benefit sharing of MGR in ABNJ.

First, a definition of deep-sea MGR is offered and a summary of their potential uses and benefits provided (section 2). Second, the international legal framework for MGR and marine scientific research in $\mathrm{ABNJ}$ is examined and compared with the regime for areas within national jurisdiction, including the Nagoya Protocol and a new EU regulation ${ }^{10}$ (section 3). Third, the emerging issues for deep-sea scientific research arising from the development of new ILBI are analysed from the perspectives of: i) how science can inform the new ILBI; and ii) how the ILBI might impact science (section 4). The qualitative results of a recent survey by the Deep-Ocean Stewardship Initiative are cited in this discussion. The paper seeks to demonstrate that the development of a new ILBI is highly relevant to deep-sea science, especially with regards to access and benefit sharing of MGR, and should engage the deepsea scientific community in order to support deep-sea stewardship in ABNJ.

\section{DEFINING DEEP-SEA GENETIC RESOURCES}

"Research on genetic resources is gradually being extended into new areas, especially the oceans which are still the planet's least explored and least well known environment. The deep-ocean in particular represents the last great frontier on the planet and is attracting growing interest in terms of research, prospecting and resource exploration" (EU, 2014).

\footnotetext{
${ }^{10}$ EU, Regulation (EU) No. 511/2014 of the European Parliament and of the Council of 16 April 2014 on compliance measures for users from the Nagoya Protocol on Access to Genetic Resources and the Fair and Equitable Sharing of Benefits Arising from their Utilization in the Union Text with EEA relevance.
} 


\subsection{What are deep-sea genetic resources?}

Legal definitions of "genetic resources" encompass a range of biological material including whole organisms, genes, proteins and naturally produced chemicals. Deep-sea genetic resources could be considered to be MGR derived from depths exceeding $200 \mathrm{~m}$. In the absence of an internationally agreed definition of MGR, a definition can be inferred from terms defined in the 1992 Convention on Biological Diversity (CBD) and Nagoya Protocol (Table 1). Deep-sea genetic resources could thus be considered to include: material from deep-sea animals, microbes or other organisms, and parts thereof containing functional units of heredity of actual or potential value (see for example, Vierros et al., 2015). On this basis, deep-sea genetic resources include primary metabolites, such as nucleosides and amino acids (i.e. genes, proteins and enzymes), and secondary metabolites or 'derivatives' (Table 1) which are biochemical compounds resulting from the genetic expression or metabolism of biological or genetic resources (i.e. biologically active molecules such as marine natural products). Disconnects between legal and scientific terminology will need to be identified and bridged to ensure that all scientific stakeholders are aware of the implications of a new ILBI for their research.

Deep-sea natural products account for a small but growing fraction of the total number of novel natural products described. Of the more than 1 million novel natural products described overall (Martins et al., 2014), more than 30,000 derive from marine origin and 600 derive from depths exceeding 50m (Skropeta and Wei, 2014). The majority of deep-sea natural products described originate in areas within national jurisdiction, with almost one quarter emanating from Australian waters (Skropeta and Wei, 2014). Few of the described deep-sea natural products originate from ABNJ. This could be an illustration of the high cost of undertaking deep-sea biological research in ABNJ (Broggiato et al., 2014, Juniper, 2013) and the high technological and other requirements for deep-sea natural product research (Skropeta, 2011). The number of novel deep-sea natural products described is increasing (Fig. 1). Furthermore, 75\% of the novel deep-sea natural products described between 2009 and 2013 were found to be biologically active with almost half showing anti-cancer potential (Skropeta and Wei, 2014). 
Fig. 1.

The deep-sea is recognised as a significant source of genetic resources. Marine invertebrates, in particular Porifera (Martins et al., 2014, Skropeta, 2008), and microorganisms (Abida et al., 2013, Pettit, 2011, Shimmield, 2013, Sogin et al., 2006) are the largest sources of novel marine natural products described. Viruses are an attractive source of new protein discoveries (Arrieta et al., 2010, Yooseph et al., 2007). Research relating to deep-sea genetic resources has been largely focused on invertebrates from benthic habitats and extremophiles from hydrothermal vents, which have yielded novel natural products and enzymes with a range of possible uses (Pettit, 2011). For example, enzymes from heat tolerant hyperthermophiles have been used in the production of DNA polymerase (Atomi, 2005). Deep-sea genetic resources research is still at a relatively early stage in comparison to other genetic resources research, but is recognised as a potential growth area (EU, 2014, Martins et al., 2014, Rogers et al., 2015, Skropeta and Wei, 2014). Areas for further deep-sea genetic resources research that have been identified, include organisms adapted to high pressure, oxygen minimum zones, chemosynthetic environments and pelagic environments (Robison, 2009, Rogers et al., 2015).

\subsection{Benefits}

Benefits from genetic resources could be either monetary or non-monetary (Nagoya Protocol, 2010). Monetary benefits, for example, are financial or commercial outcomes such as: payments (up-front, milestone or royalties); fees (access, license or special); research funding; joint intellectual property rights ownership and patents (Leary et al., 2009, Vierros et al., 2016). Non-monetary benefits are non-financial or non-economic outcomes such as: 1) Access to samples, data and knowledge, including the publication and sharing of scientific knowledge; 2) Collaboration and international cooperation in scientific research; 3) Capacity building and technology transfer including scientific training and access to resources, research infrastructure and technology; and 4) Other socio-economic benefits (e.g. research directed to priority needs such as health and food security). The potential benefits from MGR in $\mathrm{ABNJ}$ can be considered in these categories. Benefit sharing can be broadly defined as the action of giving a portion of advantages and profits to others (Schroeder, 2007). 
Despite the potential for deep-sea genetic resources to be used for various commercial applications there are very few examples of commercial products derived from ABNJ, including one cosmetic product and one enzyme used in the biofuels sector (Leary et al., 2009, Oldham et al., 2014). This could reflect the relatively recent emergence of deep-sea natural product research, the long time-frame of biodiscovery or the many commercial, financial and other barriers to the biodiscovery process (Martins et al., 2014). Considerable uncertainty remains as to the likelihood of deriving monetary benefits from MGR in ABNJ (Leary and Juniper, 2013), which can only be derived at the end of a long, complex and costly biodiscovery research and development process, where commercial success is not guaranteed (Fig. 2). The high estimates ${ }^{11}$ for the value of MGR, are based on potential economic value (Oldham et al., 2014) and do not sufficiently account for the externalities and potential barriers in the biodiscovery process. Biodiscovery rarely results in the production of patents and profitable products and most benefits from MGR in ABNJ will be non-monetary (Lallier et al., 2014, Oldham et al., 2014).

Non-monetary benefits from MGR in ABNJ are essentially guaranteed because they can be derived from each phase throughout a biodiscovery process - from initial collection of the MGR to the commercialisation of a product (Fig. 2). This is because research and development inherently generates knowledge and opportunities to share data and samples, cooperate internationally and derive and share other non-monetary benefits. Scientific research is the key enabler of biodiscovery and crucial for the derivation of benefits from MGR. The collection of genetic resources in the wild (in situ) - a pre-requisite for the marine biodiscovery process (Lallier et al., 2014) - is mostly undertaken for non-commercial purposes by academic, university and non-commercial researchers (EU, 2014).

Deep-sea research plays an important role in generating and sharing benefits from MGR in ABNJ. In ABNJ, deep-sea scientific research is the main actor accessing and collecting MGR in situ (Oldham et al., 2014) and generating non-monetary benefits by publishing and sharing knowledge and data, enabling access to deep-sea samples of MGR through collections, and

\footnotetext{
${ }^{11}$ Estimates for the value of MGR are high and varied, for example, the value of undiscovered anti-cancer drugs from marine origin was estimated to be US $\$ 563$ billion - 5.69 trillion in 2010 (Erwin et al, 2010).
} 
promoting international scientific cooperation. Deep-sea research is a key stakeholder in the development of a new ILBI (section 4) and the existing legal frameworks for ABNJ, marine scientific research and marine genetic resources (section 3) are all relevant to deep-sea science.

Fig. 2.

\section{INTERNATIONAL LEGAL FRAMEWORK FOR MARINE SCIENTIFIC RESEARCH AND GENETIC RESOURCES}

\subsection{The UNCLOS framework for ABNJ}

Much of the deep-sea lies in ABNJ. ABNJ comprise two distinct maritime zones established by UNCLOS: the high seas and the Area (Fig. 3). The high seas incorporate the water column beyond national jurisdiction (i.e. beyond the exclusive economic zone (EEZ) of States, measured as 200 nautical miles (M) from a coastal State's territorial sea baseline). The Area is the seabed, ocean floor and subsoil beyond national jurisdiction (UNCLOS Art 1(1)) (i.e. beyond the legal limit of the continental shelf of a coastal State). The outer limit of the continental shelf is generally $200 \mathrm{M}$ from the territorial sea baseline, however, States can place a submission with the Commission on the Limits of the Continental Shelf for an 'extended continental shelf' which can be a maximum of $350 \mathrm{M}$ from the territorial sea baseline or $100 \mathrm{M}$ from the 2,500 metre isobath (UNCLOS Art 76(5)). ${ }^{12}$

Fig. 3.

The high seas and the Area are subject to different legal regimes. The high seas are open to all States, including for scientific research, under the principle of conditional 'freedom of the high seas' (UNCLOS article 87). The governance regime for the Area is more stringent, whereby mineral resources (Table 1) are governed under the principle of 'common heritage of mankind' (UNCLOS article 136, UN, 1970), and administered by the International Seabed

\footnotetext{
${ }^{12}$ Where a State has an extended continental shelf, the resources of the seabed will be subject to the sovereign rights of the State but the water column above will be subject to the regime of the high seas.
} 
Authority. A new ILBI will need to be harmonised across the regimes for both the high seas and the Area (i.e. vertical scope) and areas within and beyond national jurisdiction (i.e. horizontal scope) (Greiber, 2013) and not undermine existing instruments (UN, 2015). The UNCLOS regime for marine scientific research and technology transfer provides a basis for accessing MGR in ABNJ.

\subsection{Marine science and technology under UNCLOS}

UNCLOS provides the international framework for marine scientific research (Part XIII) and marine technology development and transfer (Part XIV), establishing responsibilities and rights for researching States, international organisations and coastal States (Fig. 3). There are some fundamental differences in the legal regime for $\mathrm{ABNJ}$ and for areas within national jurisdiction. This distinction is almost uniquely relevant for deep-sea scientific research, which is conducted in areas both within and beyond national jurisdiction.

In areas within national jurisdiction the coastal State has the right to grant or withhold consent for the conduct of marine scientific research in its waters (UNCLOS articles 56(b)(ii) and 246). The researching State or international organisation has a duty to provide the coastal State with information relating to the marine scientific research project and comply with conditions established by the coastal State. In ABNJ the rules for marine scientific research are far more liberal (UNCLOS articles 248 and 249, Warner, 2008), all States have the right to conduct marine scientific research (UNCLOS article 238) as a freedom of the high seas. This freedom is not absolute and must be balanced with responsibilities, including the obligation to protect and preserve the marine environment and to conduct marine scientific research with appropriate scientific methods and means (UNCLOS article 240). Marine scientific research in the Area is subject to additional obligations, including that it shall be conducted for the benefit of mankind as a whole (UNCLOS article 143). For example, enhanced knowledge of marine biodiversity, including its role in providing ecosystem services and maintaining ocean health, is one of the potential benefits to all humankind from deep-sea research involving MGR in ABNJ (Juniper, 2013). 
The question of whether the freedom of the high seas should be balanced with an augmented legal obligation to make data and samples arising from research involving MGR in ABNJ freely available is likely to be a complicated discussion covering a wide range of factors and stakeholders. Considering the practical implications of these legal questions will require input from the deep-sea scientific community.

UNCLOS Parts XIII and XIV provide a foundation for the development of an access and benefit sharing regime for MGR in ABNJ that promotes international science cooperation (UNCLOS articles 242 and 243), scientific and technical capacity building, and technology transfer. UNCLOS establishes a duty to promote and facilitate marine scientific research (UNCLOS article 239) and requires that information and knowledge resulting from marine scientific research are published and shared internationally (UNCLOS article 244). These provisions are relevant for sharing non-monetary benefits that could be derived from MGR in ABNJ, however, there is scope to enhance implementation (Broggiato et al., 2014, Greiber, 2013) and deep-sea science will be an important element in ABNJ.

The existing UNCLOS framework could also challenge an access and benefit sharing regime because UNCLOS stipulates that marine scientific research must not constitute the legal basis for any claim to the marine environment or its resources (UNCLOS article 241). This could pose an issue should intellectual property rights or monetary benefits arise from MGR, given that research and development involving MGR usually begins with non-commercial scientific research (Warner, 2008). This adds further urgency to the need for the experiences of scientific research and the realities of the process of biodiscovery to be considered in the development of a new ILBI.

\subsection{Access and benefit sharing in areas within national jurisdiction: the Nagoya Protocol}

In areas within national jurisdiction the CBD and Nagoya Protocol apply to MGR in addition to UNCLOS (Fig. 3). The Nagoya Protocol establishes a legally binding international framework for accessing, using and sharing genetic resources from terrestrial and marine areas within national jurisdiction. As Parties to the Nagoya Protocol, which entered into force in 2014, mount efforts for its implementation it is almost certain that there will be impacts on 
the conduct of non-commercial and commercial scientific research (Burton and EvansIllidge, 2014, Lallier et al., 2014). The European Union (EU) is one of the first to adopt legislation on compliance measures for users in line with the Nagoya Protocol (EU, 2014). The EU regulation increases legal certainty for researchers involved in accessing and using genetic resources and addresses provider concerns relating to unauthorised uses of genetic resources (Burton and Illidge-Evans, 2014). It includes measures for facilitating, monitoring and verifying compliance by users of genetic resources (Table 1), such as:

- Due diligence. The EU regulation requires users to exercise due diligence to ascertain that genetic resources have been accessed in accordance with applicable access and benefit-sharing legislation. Best practices, such as sectoral codes of conduct, model contractual clauses and guidelines can be used to support due diligence. Users must declare that they have exercised due diligence at specific check points, including the receipt of research funding.

- Compliance measures. The EU regulation requires that users shall seek, keep and transfer either: a) the internationally recognised certificate of compliance ${ }^{13}$ or b) information relating to the date and place of access, description and source of GR, applicable rights and obligations relating to access and benefit sharing (including any permits and mutually agreed terms). If this information is insufficient or there are uncertainties about the legality of access and utilisation, users are required to obtain an access permit (or equivalent) and establish mutually agreed terms, or discontinue utilisation.

- Collections. Collections, as suppliers of genetic resources, play a key role in helping other users to comply with their obligations. The EU will establish and maintain a register of collections with demonstrated capacity to: 1) Apply standardised procedures for exchanging samples of genetic resources and related information; and 2) Use appropriate tracking and monitoring tools when exchanging samples and information with other collections.

\footnotetext{
${ }^{13}$ An "internationally recognised certificate of compliance" is a permit or equivalent issued at the time of access must be provided as evidence that the genetic resource it covers has been accessed legally (i.e. with prior informed consent of the provider and mutually agreed terms established by a competent authority) (EU, 2014).
} 
The Nagoya Protocol (and associated legal instruments, such as EU regulation) are not applicable in ABNJ. Furthermore, whilst the Nagoya Protocol (and associated legal instruments such as the EU regulation) provide examples of the options, opportunities and challenges of developing access and benefit sharing regimes, it has limited utility as a model for ABNJ. Differences in the international legal framework between areas within national jurisdiction and $\mathrm{ABNJ}$ demand a different approach for $\mathrm{ABNJ}$ :

\subsubsection{Multilateral approach needed in ABNJ}

An access and benefit sharing regime for MGR in ABNJ would require a multilateral approach, whereby benefits should arguably be shared with all humankind. In contrast, the Nagoya Protocol is premised on a bilateral arrangement between a provider State and a user. In areas within national jurisdiction, access and benefit sharing refers to an "exchange between those who grant access to a particular resource and those who provide compensation for its use" (Schroeder, 2007). A benefit-sharing arrangement for MGR in ABNJ would therefore be inherently different to the Nagoya Protocol regime. For example, in the absence of a provider State in ABNJ to grant access and share in benefits it is not clear how or by whom prior informed consent and mutually agreed terms would be agreed. One option could be for an international organisation to act as the 'provider'. However, questions remain as to whether access regulations for MGR in ABNJ are needed (section 4) and a discussion on possible institutional arrangements for such a regime is not within the scope of this paper.

\subsubsection{Liberal regime for science in $A B N J$}

The Nagoya Protocol regime is stringent by necessity as it protects the sovereign rights ${ }^{14}$ of States over genetic resources. ABNJ is not subject to sovereign rights and hence a regime for access and benefit sharing of MGR in ABNJ would arguably be more liberal than the Nagoya

\footnotetext{
${ }^{14}$ Coastal States have sovereign rights for the purpose of exploring and exploiting, conserving and managing the natural resources, whether living or non-living, of the water column (UNCLOS article 56 (1)) and continental shelf (UNCLOS article 77). No State can claim sovereign rights over any part of the international sea-bed Area or its resources (UNCLOS article 137).
} 
Protocol regime (Jaspars, 2015). A more liberal regime for MGR in ABNJ would also reflect the freedom of marine scientific research under the UNCLOS regime for ABNJ compared to the jurisdiction of coastal states over marine scientific research in areas within national jurisdiction.

Scientific and technological advances open new pathways for research and development of marine genetic resources that challenge and surpass the existing international legal framework. Research including genomics, proteomics and natural products chemistry can rapidly advance knowledge of marine genetic resources while synthetic biology can enable this knowledge to be used in biotechnology development. For example, legal issues would arise if a single MGR research activity (e.g. developing a new pharmaceutical) used material from areas both within and beyond national jurisdiction (Jaspars, 2015). Deep-sea scientific research will be an important actor in the multidisciplinary approach required to enable a new ILBI to develop governance solutions that support research and innovation.

\section{DISCUSSION: EMERGING ISSUES FOR DEEP-SEA SCIENTIFIC RESEARCH}

Enabling scientific research in ABNJ (and avoiding creating obstacles to science) will be an important priority for the development of a new ILBI. ${ }^{15}$ The importance of facilitating noncommercial scientific research in accessing genetic resources and supporting biodiversity conservation is explicitly recognised in the Nagoya Protocol and EU regulation (Nagoya Protocol, 2010, EU, 2014). Scientific research plays a critical role in accessing and sharing benefits from MGR and supporting deep-sea stewardship. Therefore a new regime for access and benefit sharing of MGR in ABNJ should arguably aim to enable non-monetary benefits to be derived and shared through the facilitation of scientific research. The deep-sea biology community is uniquely well-placed to provide advice on how the development of an access and benefit-sharing regime for MGR in ABNJ could maximise opportunities to facilitate research and deliver benefits to all humankind.

\footnotetext{
${ }^{15}$ The International Institute for Sustainable Development (2016) reported that the importance of facilitating and not creating obstacles to scientific research was noted by Australia, Canada and the US during PrepCom1.
} 
An access and benefit sharing regime for MGR in ABNJ under a new ILBI will almost certainly have implications for non-commercial deep-sea biological research. Thus there could be challenges as well as opportunities. For example, increased open access to deep-sea biological samples and data would be a positive outcome to deep-sea scientific research, (DOSI, 2016) ${ }^{16}$ as well as other commercial and non-commercial research activities involved in biodiscovery. Key focus areas could include: enhancing data sharing; improving sample sharing; facilitating international cooperation; advancing knowledge of deep-sea biodiversity; and incentivising and funding deep-sea research especially in understudied and new locations (DOSI, 2016, Oldham et al., 2014). However, there are also some concerns within the deepsea science community that a new access and benefit sharing regime for MGR in ABNJ could create administrative, financial and other burdens that could hinder research. ${ }^{17}$

\subsection{Accessing MGR in ABNJ in situ}

There are a number of possible access options for MGR in ABNJ that a new ILBI might consider, ranging from open unrestricted access (status quo) to strict controls (e.g. a permit). Views on this appear to be mixed, both within the deep-sea scientific community (DOSI, 2016) and within States (International Institute for Sustainable Development, 2016). Introducing access measures, if poorly handled, could run a risk of restricting scientific freedoms or imposing administrative and bureaucratic burdens.

On the other hand, a monitoring and notification system, based on existing practices in the scientific community, could be an effective way to support access and benefit sharing of MGR in ABNJ. An international code of conduct for accessing MGR in ABNJ, or some other soft law instrument that set out clear rules and simple procedures, could facilitate the adoption of standardised methods for the collection, curation, storage and sharing of

\footnotetext{
${ }^{16}$ DOSI 2016: $74 \%$ of survey respondents agreed or strongly agreed that "An access and benefit sharing regime for marine genetic resources in areas beyond national jurisdiction that provided increased open access to deepsea biological samples and data would be beneficial for scientific research" (15\% neither, $2.5 \%$ disagree, $7.5 \%$ strongly disagree).

${ }^{17}$ DOSI 2016: $42 \%$ of survey respondents agreed or strongly agreed that "An access and benefit sharing regime for marine genetic resources in areas beyond national jurisdiction could create administrative burdens on researchers and runs a risk of hindering scientific research and discovery" (35\% neither agree or disagree, $15 \%$ disagree, $6 \%$ strongly disagree).
} 
biological samples as well as maximise the use of samples for biological and chemical analyses. Existing initiatives such as the InterRidge code of conduct provide an example (InterRidge, 2006). However, such a code would need to be carefully prepared in consultation with (or preferably by) scientists, to strike a balance between freedom and oversight of sampling, and include a reporting mechanism to assess its effectiveness.

Limited 'light' access measures that build on existing practices within the scientific community, emphasising open access to data and sharing of knowledge, would be most likely to facilitate scientific research (DOSI, 2016, Jaspars, 2015). Whilst some States at PrepCom 1 expressed support for a pragmatic 'light' approach in the interests of supporting research and innovation, others were more sceptical and cautioned against preventing equitable benefit sharing (International Institute for Sustainable Development, 2016). The development of a new ILBI will need to balance these differing priorities.

\subsection{Sharing non-monetary benefits from MGR in ABNJ}

The importance of open access to scientific knowledge, data and biological samples to ensure that benefits arising from marine scientific research involving MGR in ABNJ can be realised for all humankind is gaining growing international attention (DOSI, 2016, Jaspars, 2015, Vierros et al., 2016, International Institute for Sustainable Development, 2016). Existing best-practice approaches in the scientific community for sharing data, information and samples and cooperating internationally provide a strong model e.g.:

- Data systems: Existing open data sharing platforms data provide important models, examples include the Ocean Biogeographic Information System (OBIS) for biodiversity and environmental data and Genbank for DNA and protein sequencing. The proposed OBIS global deep-sea biodiversity data-sharing platform (Appeltans and Webb, 2014, Mengerink et al., 2014, O'Hara et al., 2015) could be a useful tool for sharing biodiversity data relevant to MGR in ABNJ.

- International cooperation mechanisms: International cooperation enables facilitated access to research infrastructure and shared high costs of accessing and researching 
deep-sea in ABNJ (DOSI, 2016). International scientific networks are important in facilitating cooperation and engagement, for example, the International Network for the Investigation of Deep-Sea Ecosystems (INDEEP) and the Deep Ocean Stewardship Initiative (DOSI) collectively bring together 866 deep-sea experts from 44 countries (INDEEP, 2015).

- Peer reviewed publications: Publications are essential vehicles for sharing knowledge and making data readily available.

- Sample collections: Collections (e.g.: museums and national marine research institutions, Table 1) form a network of reputable institutions for storage and access of biological samples. Collections are already widely acknowledged for their role in streamlining access to ex situ repositories of data and samples of non-commercial research (Nagoya Protocol, 2010, EU, 2014).

- Standardisation: A lack of interoperability between standards and a fragmented system for discovery and retrieval of MGR data spanning different biological, molecular, chemical and oceanographic disciplines pose barriers for MGR research (ten Hoopen et al., 2015). Standardisation is recognised as important to avoid data 'silos' and enable biological data to be synthesised and used to inform decision making in ABNJ (Glover et al., 2016a). Standardised reporting requirements could support open-access to MGR data and samples by ensuring that information is made rapidly available through international databases.

Whilst existing measures could inform an access and benefit sharing regime for ABNJ, there is scope for improvements in making data and samples available and standardising approaches to allow synthesis of data. Rapid open access to taxonomic data supports baseline biodiversity knowledge in ABNJ (Glover et al., 2016b). Glover et al. (2016a) describe a methodological "end-to-end pipeline", starting with samples for use in combined DNA and morphology study, enabling rapid publication of data linked to internationally established online databases and accessible archived samples. Linking data across disciplines is also important. Ten Hoopen et al. (2015) describe the development of a reporting standard to support data collection and dissemination for marine microbial sampling that collaboratively builds on scientific best-practice in oceanographic, biodiversity and molecular disciplines. 
These examples could provide useful models for considering new approaches to share nonmonetary benefits from MGR in ABNJ (i.e. data, samples and knowledge).

In addition to shaping solutions to access MGR in ABNJ and generate new data, deep-sea scientists could also highlight opportunities to maximise access to and use of existing data and samples that have already been collected and await analysis. Before developing new access and benefit sharing measures, such as a common pool for MGR in ABNJ, it will important to understand the existing mechanisms used for data and sample access and exchange. Deep-sea scientific researchers are uniquely well placed to inform discussions on sharing biological samples from deep-sea ABNJ.

\subsection{Funding \& implementation?}

Implementing access and benefit sharing measures for MGR in ABNJ will require resources. The costs of collecting, curating and sharing samples and data are high. Accessing deep-sea research infrastructure and funding the development, use and maintenance of research vessels and equipment are already potential obstacles for deep-sea research (DOSI, 2016), especially in developing countries with limited deep-sea research resources (Juniper, 2013). It is not clear at this early stage what the costs might be, however, options for funding and implementation of access and benefit sharing should be considered as the development of an ILBI matures. Deep-sea scientists, research managers, national data centres and international science and data networks could advise and help shape viable solutions. For example, experience in integrating long-term data management requirements into project plans and budgets (Glover et al., 2016a) and implementing access and benefit sharing provisions of the Nagoya Protocol will be instructive.

Strengthening marine scientific capacity in developing States and transfer of marine technology will be a critical priority for a new ILBI. Examples of marine technology include: data, knowledge, skills, methodologies and research equipment (Intergovernmental Oceanographic Commission, 2005). Scientific training, opportunities to participate in deepsea research cruises, researcher exchanges and international cooperation in scientific research are some elements that could be included for an ILBI. However, designing effective measures 
will require a sound understanding of existing capacity, requirements and aspirations in developing States. The Intergovernmental Oceanographic Commission would be well-placed to support discussions on this issue.

\subsection{Engagement}

Input from the scientific community at an early stage could ensure that a new ILBI enables and does not hinder marine scientific research. The need for engagement with the marine scientific community in order to address governance challenges of MGR in ABNJ is increasingly recognised (Broggiato et al., 2014, Glowka, 2010, Glowka, 1996, Leary and Juniper, 2013, McMeel et al., 2014, Oldham et al., 2014, Vierros et al., 2016). National research organisations, scientific committees and international networks could all have roles to play. DOSI and INDEEP are important platforms to provide expert scientific input to the development of a new ILBI, especially in relation to MGR in ABNJ (Juniper and Baker, 2015, DOSI, 2016). ${ }^{18}$ For example, the DOSI Deep-Sea Genetic Resources Working Group made a submission to the first Preparatory Committee meeting for the development of new ILBI (DOSI, 2016), drawing on a survey of DOSI and INDEEP members which generated 49 responses from 18 countries. $^{19}$

While it remains unclear to what extent the development of a new ILBI might help or hinder research, it is certainly an opportunity to draw international attention to deep-sea research. First, it could highlight the importance of deep-sea research in generating baseline information and knowledge that can inform environmental impact assessments, area-based management and decision making in ocean governance. Second, it could draw international attention to knowledge gaps about deep-sea biodiversity and ecosystems, highlighting the

\footnotetext{
${ }^{18} 95 \%$ of respondents to the DOSI survey indicated that INDEEP \& DOSI play important roles in international cooperation (DOSI, 2016).

${ }^{19}$ See for example DOSI Deep-Sea Genetic Resources Working Group Deep-Sea Marine Scientific Research And Genetic Resources In Areas Beyond National Jurisdiction: Submission [to PrepCom1], 22 March 2016, http://dosi-project.org/wpcontent/uploads/2015/08/COMBINED_DOSI_DeepSeaGeneticResources_PrepComSubmission_Surveyresults. pdf or http://www.un.org/depts/los/biodiversity/prepcom_files/DOSI.pdf (accessed 04/04/2016). The DOSI submission highlighted the role of the deep-sea scientific community in aiding the development of solutions for access and benefit sharing of MGR in ABNJ.
} 
need to advance understanding through increased scientific research. Third, it could raise the profile of deep-sea scientific research needs, such as access, technical and financial resources, cooperation mechanisms, training and capacity development and marine technology development and transfer. The deep-sea scientific community could seek opportunities to ensure that negotiators are aware of the opportunities for deep-sea research to help develop, and be impacted by, a new ILBI.

\section{CONCLUSION}

Deep-sea genetic resources offer a range of potential commercial and non-commercial applications and are a growing area of research. Gaps in the international legal framework and imbalances in capacity between developed and developing States prompted MGR to be a key element for the development of a new ILBI. This raises opportunities and challenges for deep-sea scientific research, which is often the first step in accessing MGR in ABNJ and deriving and sharing benefits from their use.

Non-monetary benefits (e.g. knowledge, data, samples) are a precursor to monetary benefits and more immediate and likely outcomes from MGR in ABNJ. The facilitation of scientific research and technological innovation should thus be a priority for a new ILBI. The Nagoya Protocol is of limited use in developing options for ABNJ, however, it does set a precedent that highlights the importance of the scientific community in access and benefit sharing. A new ILBI could enhance the implementation of existing provisions under UNCLOS relating to marine scientific research, international cooperation, capacity building, and technology transfer to support access and benefit sharing of MGR in ABNJ.

The development of a new ILBI represents an ambitious effort by the international community to improve deep-sea stewardship. The expertise of deep-sea scientific researchers can play a critical role in developing practical solutions for facilitating access and benefit sharing of MGR in ABNJ as part of an ILBI. This paper hopes to stimulate discussion in the international deep-sea scientific community about how the development of a new ILBI is relevant to deep-sea science and how, in turn, deep-sea science could inform its development. 
Table 1: Definitions of terms relating to genetic resources provided in international law.

\begin{tabular}{|c|c|c|}
\hline Term & Definition & Source \\
\hline $\begin{array}{l}\text { Biological } \\
\text { diversity }\end{array}$ & $\begin{array}{l}\text { "(... variability among living organisms from all sources } \\
\text { including, inter alia, terrestrial, marine and other aquatic } \\
\text { ecosystems and the ecological complexes of which they } \\
\text { are part: this includes diversity within species, between } \\
\text { species and of ecosystems...)" }\end{array}$ & CBD article 2 \\
\hline $\begin{array}{l}\text { Biological } \\
\text { resources }\end{array}$ & $\begin{array}{l}\text { "(... includes genetic resources, organisms or parts } \\
\text { thereof, populations, or any other biotic component of } \\
\text { ecosystems with actual or potential use or value for } \\
\text { humanity...)" }\end{array}$ & CBD article 2 \\
\hline Biotechnology & $\begin{array}{l}\text { "(... any technological application that uses biological } \\
\text { systems, living organisms, or derivatives thereof, to } \\
\text { make or modify products or processes for specific } \\
\text { use... }) "\end{array}$ & CBD article 2 \\
\hline Collection & $\begin{array}{l}\text { "(... a set of collected samples of genetic resources and } \\
\text { related information that is accumulated and stored, } \\
\text { whether held by public or private entities...)" }\end{array}$ & $\begin{array}{l}\text { EU Regulation } \\
511 / 2014 \text { article } \\
3(9)\end{array}$ \\
\hline Derivative & $\begin{array}{l}\text { "(... a naturally occurring biochemical compound } \\
\text { resulting from the genetic expression or metabolism of } \\
\text { biological or genetic resources, even if it does not } \\
\text { contain functional units of heredity...)" }\end{array}$ & $\begin{array}{l}\text { Nagoya Protocol } \\
\text { article } 2(\mathrm{e})\end{array}$ \\
\hline $\begin{array}{l}\text { Genetic } \\
\text { material }\end{array}$ & $\begin{array}{l}\text { "(... any material of plant, animal, microbial, or other } \\
\text { origin containing functional units of heredity...)" }\end{array}$ & CBD article 2 \\
\hline $\begin{array}{l}\text { Genetic } \\
\text { resources }\end{array}$ & "(... genetic material of actual or potential value... $) "$ & CBD article 2 \\
\hline $\begin{array}{l}\text { Resources (as } \\
\text { referred to in } \\
\text { UNCLOS Part } \\
\text { XI [the Area]) }\end{array}$ & $\begin{array}{l}\text { "(... all solid, liquid or gaseous mineral resources in situ } \\
\text { in the Area at or beneath the seabed, including } \\
\text { polymetallic nodules...)" }\end{array}$ & $\begin{array}{l}\text { UNCLOS article } \\
133 \text { (a) }\end{array}$ \\
\hline $\begin{array}{l}\text { Utilization of } \\
\text { genetic } \\
\text { resources }\end{array}$ & $\begin{array}{l}\text { "(... to conduct research and development on the genetic } \\
\text { and/or biochemical composition of genetic resources, } \\
\text { including through the application of biotechnology as } \\
\text { defined in Article } 2 \text { of the Convention [on Biological } \\
\text { Diversity]...)" }\end{array}$ & $\begin{array}{l}\text { Nagoya Protocol } \\
\text { article } 2(\mathrm{c})\end{array}$ \\
\hline User & $\begin{array}{l}\text { "(... a natural or legal person that utilises genetic } \\
\text { resources or traditional knowledge associated with } \\
\text { genetic resources...)" }\end{array}$ & $\begin{array}{l}\text { EU Regulation } \\
511 / 2014 \text { article } \\
3(4)\end{array}$ \\
\hline
\end{tabular}

\section{ACKNOWLEDGEMENTS}


The author thanks Robin Warner, Mary-Ann Palma and Genevieve Quirk for providing comments on earlier drafts of this paper. The author would also like to thank Danielle Skropeta for deep-sea natural products data in Fig.1 (Skropeta, 2008, Skropeta and Wei, 2014). This paper is based on a presentation by the author to the 14th Deep-Sea Biology Symposium (Aveiro, 01 September 2015), the author gratefully acknowledges funding support from the University of Wollongong Global Challenges Program to attend at this conference. This funding source had no involvement in the research or writing of this paper.

\section{REFERENCES}

Abida, H., Ruchaud, S., Rios, L., Humeau, A., Probert, I., De Vargas, C., Bach, S., Bowler, C., 2013. Bioprospecting marine plankton. Marine Drugs 11, 4594-4611.

Appeltans, W., Webb, T.J., 2014. Biodiversity baselines in the deep sea. Deep-Sea Life 4, 45-46.

Armstrong, C.W., Foley, N.S., Tinch, R., van den Hove, S., 2012. Services from the deep: Steps towards valuation of deep sea goods and services. Ecosystem Services 2, 2-13.

Arnaud-Haond, S., Arrieta, J.M., Duarte, C.M., 2011. Marine biodiversity and gene patents. Science $331,1521-1522$.

Atomi, H., 2005. Recent progress towards the application of hyperthermophiles and their enzymes. Current Opinion in Chemical Biology 9, 166-173.

Benn, A.R., Weaver, P.P., Billet, D.S.M., van den Hove, S., Murdock, A.P., Doneghan, G.B., Le Bas, T., 2010. Human Activities on the Deep Seafloor in the North East Atlantic: An Assessment of Spatial Extent. PLoS ONE 5, e12730.

Broggiato, A., Arnaud-Haond, S., Chiarolla, C., Greiber, T., 2014. Fair and equitable sharing of benefits from the utilization of marine genetic resources in areas beyond national jurisdiction: Bridging the gaps between science and policy. Marine Policy 49, 176-185.

Burton, G., Evans-Illidge, E.A., 2014. Emerging R and D Law: The Nagoya Protocol and Its Implications for Researchers. ACS Chemical Biology 9, 588-591.

CBD, 1992. Convention on Biological Diversity, opened for signature 5 June 1992, 1760 UNTS 79 (entered into force 29 December 1993).

DOSI, 2016. Deep-Sea Marine Scientific Research And Genetic Resources In Areas Beyond National Jurisdiction: Submission [submission by the Deep Ocean Stewardship Initiative Working Group on 
Deep-Sea Genetic Resources, to the first Preparatory Committee meeting for the development of an international legally-binding instrument on the conservation and sustainable use of marine biological diversity in areas beyond national jurisdiction, under the United Nations Convention on the Law of the Sea], 22 March 2016, http://www.un.org/depts/los/biodiversity/prepcom files/DOSI.pdf accessed 04/04/2016.

Druel, E., Gjerde, K.M., 2014. Sustaining marine life beyond boundaries: Options for an implementing agreement for marine biodiversity beyond national jurisdiction under the United Nations Convention on the Law of the Sea. Marine Policy 49, 90-97.

Erwin, P.M., Lopez-Legentil, S., Schuhmann, P.W., 2010. The pharmaceutical value of marine biodiversity for anti-cancer drug discovery. Ecological Economics 70, 445-451.

EU, 2014. Regulation (EU) No. 511/2014 of the European Parliament and of the Council of 16 April 2014 on compliance measures for users from the Nagoya Protocol on Access to Genetic Resources and the Fair and Equitable Sharing of Benefits Arising from their Utilization in the Union Text with EEA relevance.

FAO, 2014. Common Oceans: Global Sustainable Fisheries Management and Biodiversity Conservation in Areas Beyond National Jurisdiction. FAO, Rome, 2.

German, C.R., Ramirez-Llodra, E., Baker, M.C., Tyler, P.A., Committee, a.t.C.S.S., 2011. Deepwater chemosynthetic ecosystem research during the Census of Marine Life decade and beyond: a proposed deep-ocean road map. PLoS ONE 6, 1-16.

Glover, A., Dahlgren, T., Wiklund, H., Mohrbeck, I., Smith, C., 2016a. An End-to-End DNA Taxonomy Methodology for Benthic Biodiversity Survey in the Clarion-Clipperton Zone, Central Pacific Abyss. Journal of Marine Science and Engineering 4(1), 2.

Glover, A., Wiklund, H., Rabone, M., Amon, D.J., Smith, C. R., O'Hara, T., Mah, C.L., Dahlgren, T.G., 2016b. Abyssal fauna of the UK-1 polymetallic nodule exploration claim, Clarion Clipperton Zone, central Pacific Ocean: Echinodermata. Biodiversity Data Journal 4, e7251.

Glowka, L., 1996. The Deepest of Ironies: Genetic Resources, Marine Scientific Research and the Area. Ocean Yearbook 12, 154-178.

Glowka, L., 2010. Evolving Perspectives on the International Seabed Area's Genetic Resources: Fifteen Years after the Deepest of Ironies, in: Vidas, D. (Ed.), Law, Technology and Science for Oceans in Globalisation: IUU Fishing, Oil Pollution, Bioprospecting, Outer Continental Shelf. Martinus Nijhoff, Leiden, Boston, 397-423.

Greiber, T., 2013. Meaning and Scope. Information Paper 1., IUCN Information Papers for the Intersessional Workshop on Marine Genetic Resources 2-3 May 2013, United Nations General Assembly Ad Hoc Open-ended Informal Working Group to study issues relating to the conservation and sustainable use of marine biological diversity beyond areas of national jurisdiction. IUCN Environmental Law Centre, Bonn, 1-7. 
Harden-Davies, H., 2015. The Regulation of Marine Scientific Research: Addressing Challenges, Advancing Knowledge, in: Warner, R., Kaye, S. (Eds.), Routledge Handbook of Maritime Regulation and Enforcement. Routledge, Abingdon, 212-230.

Halpern, B.S., Walbridge, S., Selkoe, K.A., Kappel, C.V., Micheli, F., D’Agrosa, C., Bruno, J.F., Casey, K.S., Ebert, C., Fox, H.E., Fujita, R., Heinemann, D., Lenihan, H.S., Madin, E.M.P., Perry, M.T., Selig, E.R., Spalding, M., Steneck, R., Watson, R., 2008. A global map of human impact on marine ecosystems. Science 319, 948-952.

Houghton, K., 2014. Identifying new pathways for ocean governance: The role of legal principles in areas beyond national jurisdiction. Marine Policy 49, 118-126.

Intergovernmental Oceanographic Commission, 2005. IOC Criteria and Guidelines on the Transfer of Marine Technology. UNESCO-IOC, Paris.

International Institute for Sustainable Development, Reporting Services Division, 2016. Summary of the First Session of the Preparatory Committee on Marine Biodiversity of Areas Beyond National Jurisdiction 28 March - 8 April, 2016. Earth Negotations Bulletin 25 (106). 1-21.

INDEEP, 2015. http://www.indeep-project.org/about-indeep-international-network-scientificinvestigation-deep-sea-ecosystems. Accessed 23/11/2015.

InterRidge, 2006. InterRidge Statement of Commitment to Responsible Research Practices at FeepSea Hydrothermal Vents. InterRidge.

Jaspars, M., 2015. Implications of Access and Benefit-Sharing (ABS) frameworks for Collection and Utilisation of Marine Biological Samples. Presentation to Workshop Side-Event, $14^{\text {th }}$ Deep Sea Biology Symposium, Aveiro, Portugal, 3 September 2015.

Juniper, S.K., Baker, M., 2015. Biological research as a deep-sea stakeholder. Conference Presentation, 14 ${ }^{\text {th }}$ Deep Sea Biology Symposium, Aveiro, Portugal, 31 August 2015.

Juniper, S.K., 2013. Technological, Environmental, Social and Economic Aspects. Information Paper 3. IUCN Information Papers for the Intersessional Workshop on Marine Genetic Resources 2-3 May 2013, United Nations General Assembly Ad Hoc Open-ended Informal Working Group to study issues relating to the conservation and sustainable use of marine biological diversity beyond areas of national jurisdiction. IUCN Environmental Law Centre, Bonn, 15-22.

Lallier, L.E., McMeel, O., Greiber, T., Vanagt, T., Dobson, A.D.W., Jaspars, M., 2014. Access to and use of marine genetic resources: understanding the legal framework. Natural Product Reports 31, 612616.

Leal, M.C., Hilario, A., Munro, M.H.G., Blunt, J.W., Calado, R., 2016. Natural products discovery needs improved taxonomic and geographic information. Natural Product Reports (in press). 
Leary, D., Juniper, S.K., 2013. Addressing the Marine Genetic Resources Issue: Is the Debate Heading in the Wrong Direction?, in: Schofield, C.H., Lee, S., and Kwon, M., (Eds.), The Limits of Maritime Jurisdiction. BRILL, Leiden, 769-785.

Leary, D., Vierros, M., Hamon, G., Arico, S., Monagle, C., 2009. Marine genetic resources: A review of scientific and commercial interest. Marine Policy 33, 183-194.

Martins, A., Vieira, H., Gaspar, H., Santos, S., 2014. Marketed marine natural products in the pharmaceutical and cosmeceutical industries: tips for success. Marine Drugs 12, 1066-1101.

Mengerink, K.J., Van Dover, C.L., Ardron , J., Baker, M., Escobar-Briones, E., Gjerde, K., Koslow, J.A., Ramirez-Llodra, E., Lara-Lopez, A., Squires, D., Sutton, T., Sweetman, A.K., Levin, L.A., 2014. A call for deep-ocean stewardship. Science 344, 696-698.

McMeel, O., Greiber, T., Vanagt, T., Jaspars, M., 2014. Report of the PharmaSea WP6 Stakeholder Workshop on 'Options for an Access and Benefit-Sharing Regime for Marine Genetic Resources from Areas Beyond National Jurisdiction'. PharmaSea-eCOAST-6.8a, Ostend.

Nagoya Protocol., 2010. Nagoya Protocol on Access to Genetic Resources and the Fair and Equitable Sharing of Benefits Arising from their Utilization to the Convention on Biological Diversity, opened for signature 29 October 2010 (entered into force 12 October 2014).

Oldham, P., Hall, S., Barnes, C., Oldham, C., Cutter, M., Burns, N., Kindness, L., 2014. Valuing the Deep: Marine Genetic Resources in Areas Beyond National Jurisdiction, Defra Contract MB0128 - A review of current knowledge regarding marine genetic resources and their current and projected economic value to the UK economy. Final Report Version One. One World Analytics, London.

O’Hara, T., Tittensor, D., Baker, M., Stocks, K., Appeltans, W., 2015. A Global Deep-Sea Biodiversity Data-Sharing Platform. Deep-Sea Life 6, 12.

Pettit, R., 2011. Culturability and Secondary Metabolite Diversity of Extreme Microbes: Expanding Contribution of Deep Sea and Deep-Sea Vent Microbes to Natural Product Discovery. Marine Biotechnology 13, 1-11.

Ramirez-Llodra, E., Tyler, P.A., Baker, M.C., Bergstad, O.A., Clark, M.R., Escobar, E., Levin, L.A., Menot, L., Rowden, A.A., Smith, C.R., Van Dover, C.L., 2011. Man and the Last Great Wilderness: Human Impact on the Deep Sea. PLoS ONE 6, e22588.

Robison, B.H., 2009. Conservation of Deep Pelagic Biodiversity. Conservation Biology 23(4), 847.

Rochette, J., Wright, G., Gjerde, K.M., Greiber, T., Unger, S., Spadone, A., 2015. A New Chapter for the High Seas? IDDRI, Paris. 
Rogers, A., Brierley, A., Croot, P., Cunha, M., Danovaro, R., Devey, C., Hoel, A., Ruhl, H., Sarradin, P.-M., Trevisanut, S., van den Hove, S., Vieira, H., Visbeck, M., 2015. Delving Deeper: Critical challenges for 21 st century deep-sea research, Ostend.

Rogers, A., Sumaila, U., Hussain, S., Baulcomb, C., 2014. The High Seas and Us: Understanding the Value of High Seas Ecosystems. Global Ocean Commission, Oxford.

Schroeder, D., 2007. Benefit sharing: it's time for a definition. Journal of Medical Ethics 33, 205-209.

Shimmield, G., 2013. Extent and Types of Research, Uses and Applications. Information Paper 2., IUCN Information Papers for the Intersessional Workshop on Marine Genetic Resources 2-3 May 2013, United Nations General Assembly Ad Hoc Open-ended Informal Working Group to study issues relating to the conservation and sustainable use of marine biological diversity beyond areas of national jurisdiction. IUCN Environmental Law Centre, Bonn, 7-15.

Skropeta, D., 2011. Exploring Marine Resources for New Pharmaceutical Applications, in: Gullett, W., Schofield, C., Vince, J. (Eds.), Marine Resources Management. LexisNexis Butterworths, Chatswood, 211-224.

Skropeta, D., 2008. Deep-sea natural products. Natural Product Reports 25, 1131-1166.

Skropeta, D., Wei, L., 2014. Recent advances in deep-sea natural products. Natural Product Reports 31, 999-1025.

Sogin, M.L., Morrison, H.G., Huber, J.A., Welch, D.M., Huse, S.M., Neal, P.R., Arrieta, J.M., Herndl, G.J., 2006. Microbial diversity in the deep sea and the underexplored "rare biosphere". Proceedings of the National Academy of Sciences 103, 12115-12120.

ten Hoopen, P., Pesant, S., Kottman, R., Kopf, A., Bicak, M., Claus, S., Deneudt, K., Borremans, C., Thijsse, P., Dekeyzer, S., Schaap, D.M.A., Bowler, C., Glockner, F.O., Cochrane, G., 2015. Marine microbial biodiversity, bioinformatics and biotechnology (M2B3) data reporting and service standards. Standards in Genomic Sciences 10(20), 1-10.

UN, 2015. United Nations General Assembly (UNGA) Resolution 69/292. 'Development of an international legally-binding instrument under the United Nations Convention on the Law of the Sea on the conservation and sustainable use of marine biological diversity of areas beyond national jurisdiction' of 19 June 2015.

UN, 2010. United Nations Division for Ocean Affairs and the Law of the Sea Office of Legal Affairs, 2010. Marine Scientific Research: A revised guide to the implementation of the relevant provisions of the United Nations Convention on the Law of the Sea. United Nations, New York.

UN, 1970. United National General Assembly (UNGA) Resolution 25/2749. 'Declaration of Principles Governing the Sea-Bed and the Ocean Floor, and the Suboil Thereof, beyond the Limits of National Jurisdiction' of 17 December 1970. 
UNCLOS, 1982. United Nations Convention on the Law of the Sea, opened for signature 10 December 1982, 1833 UNTS 3 (entered into force 16 November 1994).

Van Dover, C.L., 2014. Impacts of anthropogenic disturbances at deep-sea hydrothermal vent ecosystems: A review. Marine Environmental Research 102, 59-72.

Van Dover, C.L., Aronson, J., Pendleton, L., Smith, S., Arnaud-Haond, S., Moreno-Mateos, D., Barbier, E., Billett, D., Bowers, K., Danovaroj, R., Edwards, A., Kellert, S., Moratom, T., Pollardn, E., Rogers, A., Warner, R., 2014. Ecological restoration in the deep sea: Desiderata. Marine Policy 44, 98-106.

Vierros, M., Suttle, C., Harden-Davies, H., Burton, G., 2016. Who owns the ocean? Policy issues surrounding marine genetic resources. Limnology and Oceanography Bulletin (in press).

Vierros, M., Salpin, C., Chiarolla, C., Arico, S., 2015. Emerging and resolved issues: the example of marine genetic resources of areas beyond national jurisdiction, in: Arico, S. (Ed.), Ocean Sustainability in the 21st Century. Cambridge University Press; UNESCO Publishing, Cambridge, pp. 198-231.

Warner, R., 2008. Protecting the diversity of the depths: environmenal regulation of bioprospecting and marine scientific research beyond national jurisdiction. Ocean Yearbook 22, 411-443.

Warner, R.M., 2014. Conserving Marine Biodiversity in the Global Marine Commons: Co-evolution and Interaction with the Law of the Sea. Frontiers in Marine Science 1.

Wright, G., Rochette, J., Druel, E., Gjerde, K., 2016. The long and winding road continues: Towards a new agreement on high seas governance. Study No.01/16, IDDRI, Paris. 50p.

Yooseph, S., Sutton, G., Rusch, D.B., Halpern, A.L., Williamson, S.J., Remington, K., Eisen, J.A., Heidelberg, K.B., Manning, G., Li, W., Jaroszewski, L., Cieplak, P., Miller, C.S., Li, H., Mashiyama, S.T., Joachimiak, M.P., van Belle, C., Chandonia, J.-M., Soergel, D.A., Zhai, Y., Natarajan, K., Lee, S., Raphael, B.J., Bafna, V., Friedman, R., Brenner, S.E., Godzik, A., Eisenberg, D., Dixon, J.E., Taylor, S.S., Strausberg, R.L., Frazier, M., Venter, J.C., 2007. The Sorcerer II Global Ocean Sampling Expedition: Expanding the Universe of Protein Families. PLoS Biology 5, e16. 